\title{
MAECENAS BETWEEN APOLOGIES AND ANTHOLOGIES: PAST SCHOLARSHIP AND NEW RESEARCHES*
}

Summary: Maecenas' character has been handed down variously and sometimes contradictorily by ancient sources; modern critics have contributed even more to stress extravagant features of his personality and writings. This paper aims to highlight the most important ways of interpretation and to suggest new hints of research starting from a re-analysis of texts.

Key words: Maecenas, Fortleben, Latin literature, poetics, ethics

Recalling a learned conversation with friends on the Age of Augustus, Marquis JeanLouis Guez de Balzac wrote to Marquise de Rambouillet what would become the fifth speech of his Euvres diverses, in order to satisfy her curiosity about Maecenas. In the few lines I have quoted here below, it is clear that his character, at that time as nowadays, had been overshadowed by Augustus.

Auguste fut couronné par le suffrage de toute la compagnie [...] Mais parce qu'Agrippa et Mecenas furent oubliez en cette Vie, vous me témoignastes [...] que vous ne seriez pas faschée que je vous contasse ce que je pouvois sçavoir de l'un et de l'autre, et que je vous ferois encore plus de plaisir, si je vous voulois faire une particuliere Relation de Mecenas, de qui tant de gens parlent, sans le connoistre. [...] je vous donneray les choses [...] selon qu'elles me viendront à l'esprit ; et dans la liberté de la Conversation. ${ }^{1}$

* I am going to maintain as much as possible form and structure of the oral conference, limiting bibliography to the absolute necessary and pointing out studies I have not quoted in other contributions on the same subject. Where there are no indications, English translations are mine; otherwise, I have taken them from the volumes of Loeb Classical Library, Cambridge, Mass. (except for Fr. 3 Lund.).

${ }^{1}$ GUEZ DE BALZAC, J.-L.: Euvres diverses. Rouen $1658^{2}, 113$. 
Augustus was crowned by a general admiration [...] Anyway, as in the narrative of his life Agrippa and Maecenas were forgotten, You told me [...] You would have pleasure to apprehend what I know about them both, and in particular about Maecenas, who is on everyone's lips, even if nobody actually knows who he was. [...] I'm going to tell You the information You have asked for, as they come to my mind and in a very informal way.

I am sure that Maecenas is better known among the readers of this paper than in Marquise's drawing-room. Nevertheless, I do not consider inopportune a rapid survey of the ancient sources; the Latin sources, in particular, on Maecenas form an anthological series of sporadic testimonies rather consistent with each other, but poor of information, especially when compared to the fame (or rather the myth) of the character.

The biographers of the twentieth century ${ }^{2}$ understandably interested in providing the fullest possible picture of Maecenas, often pay more attention to his character than to the context of the source and to the purposes of the authors, in order to draw from the source more than what it actually says. Maecenas' portraits obtained by Avallone and André are undeniably satisfactory and reliable, but as a scholar of Latin literature I would like to obtain from the sources a more neutral picture of this cornerstone of the age of Augustus. Like the Marquis de Balzac I will proceed dans la liberté de la conversation and with a drastic selection of passages, starting with some sources on Maecenas' political role.

It is indicative that the richest source of details on this important Roman character of the first century BC is a Greek historian of the third century AD, Dio Cassius, who describes a council where Maecenas illustrates to Augustus the guide-lines of the imperial government (52. 14-40). As a Latinist, I will leave out of consideration this source, finding support from a sentence of Gibbon, who considered the historian scarcely reliable on this topic ${ }^{3}$; I must anyway admit that, at first glance, the conciseness of the only Latin sources can leave one disappointed or, at least, puzzled. Velleius Paterculus, for example, describes very clearly Maecenas' very obscure features (Vell. Pat. 2. 88. 2-3):

〈erat〉 tunc urbis custodiis praepositus $C$. Maecenas, equestri sed splendido genere natus, uir, ubi res uigiliam exigeret, sane exsomnis, prouidens atque agendi sciens, simul uero aliquid ex negotio remitti posset, otio ac mollitiis paene ultra feminam fluens, non minus Agrippa Caesari carus sed minus honoratus (quippe uixit angusti claui tpaenet contentus), nec minora consequi potuit sed non tam concupiuit. Hic speculatus est per summam quietem ac dissimulationem praecipitis consilia iuuenis [scil.

\footnotetext{
${ }^{2}$ Avallone, R.: Mecenate. Napoli 1962; ANDRÉ, J.-M.: Mécène. Paris 1967.

${ }^{3}$ GIBBON, E.: The Decline and Fall of the Roman Empire. London 1993, vol. 1, 40, n. 3 "We may suspect that the historian Dio was the author of a counsel so much adapted to the practice of his own age, and so little to that of Augustus"; similarly GIBBON, vol. 1, 70, n. 2 about Augustus' language. BALBO, A.: I frammenti degli oratori romani dell'età augustea e tiberiana. Parte prima: Età augustea. Alessandria $2007^{2}, 21-22$ has recently summed up six good reasons to consider fictitious Maecenas' discourse de regno.
} 
Lepidi] et mira celeritate nullaque cum perturbatione aut rerum aut hominum oppresso Lepido, immane noui ac resurrecturi belli ciuilis restinxit initium.

The guards of the city were at that time under the charge of Gaius Maecenas, of equestrian rank, but none the less of illustrious lineage, a man who was literally sleepless when occasion demanded, and quick to foresee what was to be done and skilful in doing it, but when any relaxation was allowed him from business cares would almost outdo a woman in giving himself up to indolence and soft luxury. He was not less loved by Caesar than Agrippa, thought he had fewer honours heaped upon him, since he lived thoroughly content with the narrow stripe of equestrian order. He might have achieved a position no less high than Agrippa, but had not the same ambition for it. Quietly and carefully concealing his activity he unearthed the plans of the hot-headed youth, and by crushing Lepidus with wonderful swiftness and without causing disturbance to either men or things he extinguished the portentous beginnings of a new and reviving civil war. [trans. F.W. Shipley ${ }^{4}$ ]

Even if we overlook the most "paradoxical" - and well known - aspects of his eccentric behaviour, Maecenas turns out, however, to be an ambiguous figure of a man who could unofficially do everything while officially he was nothing.

We get the same impression from reading another great historian: Tacitus (ann. 3. 30), who even more ambiguously shows us Maecenas behind the figure of his successor Sallust Crispus (grandson of Sallust the historian).

atque ille [scil. Sallustius Crispus], quamquam prompto ad capessendos honores aditu, Maecenatem aemulatus sine dignitate senatoria multos triumphalium consulariumque potentia antiit, diversus a veterum instituto per cultum et munditias copiaque et affluentia luxu propior. suberat tamen vigor animi ingentibus negotiis par, eo acrior quo somnum et inertiam magis ostentabat. igitur incolumi Maecenate proximus, mox praecipuus, cui secreta imperatorum inniterentur, et interficiendi Postumi Agrippae conscius, aetate provecta speciem magis in amicitia principis quam vim tenuit. idque et Maecenati acciderat, fato potentiae raro sempiternae, an satias capit aut illos cum omnia tribuerunt aut hos cum iam nihil reliquum est quod cupiant.

Thus for him the avenue to the great offices lay clear; but, choosing to emulate Maecenas, without holding senatorial rank he outstripped in influence many who had won a triumph or the consulate; while by his elegancy and refinements he was sundered from the old Roman school, and in the ample and generous scale of his establishment approached extrava-

\footnotetext{
${ }^{4}$ Velleius Paterculus, Compendium of Roman History. Trans. by F. W. SHIPLEY. London-Cambridge Mass. 1979.
} 
gance. Yet under it all lay a mental energy, equal to gigantic task, and all the more active from the display he made of somnolence and apathy. Hence, next to Maecenas, while Maecenas lived, and later next to none, he it was who sustained the burden of the secrets of emperors. He was privy to the killing of Agrippa Postumus; but with advancing years he retained more the semblance than the reality of his sovereign's friendship. The same lot had fallen to Maecenas also, - whether influence, rarely perpetual, dies a natural death, or there comes a satiety, sometimes to the monarch who has no more to give, sometimes to the favourite with no more to crave [trans. J. Jackson ${ }^{5}$ ]

In Tacitus' description of Maecenas we find the same hidden (and dissimulated) alacrity, the informal power greater than the formal one, the authority based on personal favour (amicitia principis $\sim$ Caesari carus), which can be weakened but does not completely disappear (speciem magis ... quam vim). All this is set in a gloomy picture of secrets and conspiracies of the palace so that the character of Maecenas in politics should not be restricted to the idealized image of the good emperor's wise counsellor. ${ }^{6}$

P. White, who seeks excellently to establish the story of the career of Maecenas, deems, understandably, these lines of Tacitus as "irritant"; on the other hand, the Tacitean commentator E. Koestermann appreciates them as "eine der wichtigen Stellen, an denen Tacitus über die Beständigkeit der Macht nachgrübelt und Klarheit zu gewinnen sucht, welche Faktoren für das Verhältnis zwischen den Machthabern und ihren vertrauten Ratgebern entscheidend sind", ${ }^{8}$ and M. A. Levi draws from this passage of Tacitus the best definition of Maecenas' power, considering it a typical political product of the Augustan Age: "Mecenate [...] era il responsabile di tutta la gestione politica, culturale ed economica di una casata i cui poteri reali soverchiavano quelli dello stato, ma che formalmente era sempre una casa privata [...]. Soltanto se si arriva a capire la situazione in cui si trovava e operava Augusto si può arrivare a ca-

\footnotetext{
${ }^{5}$ Tacitus, The Annals. Trans. by J. JACKSON. London-Cambridge Mass. 1969.

${ }^{6}$ An idealization recently re-proposed by Le DOzE, PH.: Quomodo Maecenas vixerit: à propos du Mécène de Sénèque. Latomus 71 (2012) 731-752, here 747, mainly based on Dio Cassius' loci; among Maecenas' advices to Augustus we can recall this famous one, about Agrippa's destiny (Dio Cassius 54. 6. 5

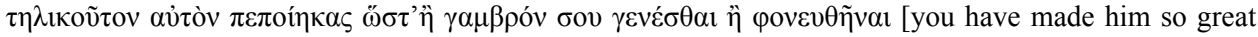
that he must either become your son-in-law or be slain; cf. Dio Cassius, Roman History. Trans. by E. CARY. London-Cambridge Mass. 1961]); in this sentence an ironical cynism typical of palace plot is, in my opinion, undeniable.

${ }^{7}$ WHITE, P.: Maecenas' Retirement. CPh 86 (1991) 130-138, here 133-134.

${ }^{8}$ KoestermanN, E.: Cornelius Tacitus. Annalen I. Buch 1-3. Heidelberg 1963, 478 "one of the most important passages where Tacitus tries to explore the durability of power and to identify what factors are substantial for the relationship between dynasts and their intimate advisers"; about the supposed fall in disgrace of Maecenas I refer to LE DOZE, PH.: Aux origines d'une retraite politique: Mécène et la Res publica restituta. In HuRLET, F. - MineO, B. (éds.): Le Principat d'Auguste. Réalités et répresentations du pouvoir Autour de la Res publica restituta. Rennes 2009, 101-118, here 102 (I thank Martin Spannagel for having informed me about this paper); his further considerations about Maecenas' otium in LE DOZE: Quomodo (n. 6) 746-751 are in my opinion too conjectural.
} 
pire quella personale in cui si trovava a operare Mecenate. [...] La funzione di Mecenate è quindi singolare e unica, proprio perché singolare e unico è il potere di Augusto."

Tacitus, as a skilful authority on the Julio-Claudian court, can be considered trustworthy enough in my opinion when he describes - as far as possible - a political power which, in fact, was a palace secret and whose essence (the amicitia principis) was celebrated as well by less subtle sources; let us see how Propertius singles out the true glory of Maecenas in his fides towards Augustus (Prop. 2. 1. 35-36; 3. 9. 33$34)^{10}$

Te mea Musa illis semper contexeret armis [scil. Caesaris] et sumpta et posita pace fidele caput.

(Prop. 2. 1.35-36)

so oft would my Muse weave thy name into those deeds, true hearth in peace or war [trans. H. E. Butler ${ }^{11}$ ]

Caesaris et famae vestigial iuncta tenebis:

Maecenatis erunt vera tropaea fides.

thy footsteps shall accompany the fame of Caesar; thy loyalty, Maecenas, shall be thy true trophy of triumph [trans. H. E. Butler]

Similarly notable is the categorical consideration used by the anonymous writer of the Elegies (a posthumous apology to Maecenas of uncertain date) ${ }^{12}$ to justify the eccentric behaviour of Maecenas: El. 103 Caesar amicus erat. Poterat vixisse solute ("he was Caesar's friend, he could delicately live"). One last source on this topic is Sen. ben. 6.32.2;4, which concerns an episode of Augustan internal policy, about the scandal that followed Julia's relegatio and the divulgence of her gossip:

"Horum mihi nihil accidisset, si aut Agrippa aut Maecenas vixissent!" Adeo tot habenti milia hominum duos reparare difficile est. [...] Non est, quod existimemus Agrippam et Maecenatem solitos illi vera dicere; qui si vixissent, inter dissimulantes fuissent. Regalis ingenii mos est in praesentium contumeliam amissa laudare et his virtutem, dare vera dicendi, a quibus iam audiendi periculum non est. (Sen. ben.6.32.2 and 4)

"If either Agrippa or Maecenas had lived, none of this would have happened to me!" So difficult is it for one who had so many thousands of men

${ }^{9}$ LEVI, M. A.: Mecenate e Augusto. RSA 25 (1995) 143-147, here 145-146 "Maecenas [...] was responsible for the overall political, cultural and economic management of a lineage whose power actually overwhelmed that of the state, but formally it always remained a private home [...]. Only if we are aware of the situation in which Augustus established himself and worked, can we understand the situation in which Maecenas operated. [...] Maecenas' role was so exclusive and particular because Augustus' power was exclusive and particular."

${ }^{10}$ Fides is a very traditional Romana virtus; Propertius is probably going to bestow on Maecenas a feature worthy of a vir Romanus (see CAIRNS, F.: Sextus Propertius. The Augustan Elegist. Cambridge 2006, 293)

${ }_{11}^{11}$ Propertius, Elegies. Trans. by H. E. BuTLER. London-Cambridge Mass. 1967.

${ }^{12}$ The most recent study, LE DOZE, PH.: Elegiae in Maecenatem. Un regard sur Mécène. Athenaeum 100 (2012) 291-301, here 292 is inclined to an Augustan dating. 
to repair the loss of two! [...] There is no reason for us to suppose that Agrippa and Maecenas were in habit of speaking the truth to him; they would have been among the dissemblers if they had lived. It is a characteristic of the kingly mind to praise what has been lost to the detriment of what is present, and to credit those with the virtue of telling the truth from those to whom there is no longer any danger of hearing it.

$$
\text { [trans. J. W. Basore }{ }^{13} \text { ] }
$$

This Senecan passage is an often mistreated testimony: superficial readers consider it a simple proof of confidence and esteem of the prince for his counsellor. The apologists for Maecenas perceive in this text a proof of Seneca's malice against Maecenas, featured as a hypocritical courtier. ${ }^{14}$ Nowadays, while the critical interest in this important socio-political treatise is increasing, ${ }^{15}$ the best definition of these pages has been given, in my opinion, by M. T. Griffin: as a courtier and amicus principis himself, Seneca seems to be the most qualified author to give information about another man of the court. ${ }^{16}$ To conclude: Maecenas, minister without a ministry, has really been able to conceal and disguise his role since several of the finest Latin authors have been able to say so little about him. The elusiveness of Maecenas' power exemplifies the elusiveness of Augustus' political media. ${ }^{17}$

Seneca moreover is the author who has chiefly developed the criticism of Maecenas' eccentric behaviour, which is clearly, but soberly, testified by historians as well; Sen. ep. 114. 6, quoted here below, is only one of the several well-known Senecan texts in Maecenatem:

Non statim cum haec legeris hoc tibi occurret, hunc esse qui solutis tunicis in urbe semper incesserit (nam etiam cum absentis Caesaris partibus fungeretur, signum a discincto petebatur); hunc esse qui (in) tribunali, in rostris, in omni publico coetu sic apparuerit ut pallio velaretur caput exclusis utrimque auribus, non aliter quam in mimo fugitivi divitis solent; hunc esse cui tunc maxime civilibus bellis strepentibus et sollicita urbe et armata comitatus hic fuerit in publico, spadones duo, magis tamen viri quam ipse.

${ }^{13}$ Seneca, Moral Essays. Trans. by JOHN W. BASORE. London-Cambridge Mass. 1964.

${ }^{14}$ Avallone (n. 2) 1962, 67 n. 43 defines Seneca as "giudice per nulla sereno"; ANDRÉ (n. 2) 80 "speculation désobligeant de Sénèque".

${ }^{15}$ We can remember GRIfFIn, M.: Seneca on Society. A Guide to De Beneficiis. Oxford 2013; the research group of the Universities of Verona, Siena and Palermo; Giancarlo Mazzoli's forthcoming edition with text, translation and commentary of the treatise.

${ }^{16}$ GRIFFIN (n. 15) 82: "Seneca exposes, in a tone suggestive of firsthand experience, the difficulties confronting 'friends of the Princeps' who actually try to do this. [...] Seneca's position at court will have given him ample opportunity to observe and experience the issues surrounding the exchange of beneficia with the Emperor."

${ }^{17}$ LE DOZE: Aux origines (n. 8) 110, after a good survey of historical sources, has to bow to the (un)evidence: "il demeure difficile de cerner exactement la nature des pouvoirs du ministre d'Octavien, dont on perçoit néanmoins qu'ils furent très importants". 
Can you not imagine, on reading through these words, that this was the man who always paraded through the city with a flowing tunic? For even if he was discharging the absent emperor's duties, he was always in undress when they ask him for the countersign. Or that this as the man who, as judge on the bench, or as an orator, or at any public function, appeared with his cloak wrapped about his head, leaving only the ears exposed like the millionaire's runaway slave in the farce? Or that this was the man who, at the very [?] time when the state was embroiled in civil strife, when the city was in difficulties and under martial law, was attended in public by two eunuchs - both of them more men than himself?

$$
\text { [trans. R. M. Gummere }{ }^{18} \text { ] }
$$

Maecenas' biographers have pointed out the partiality of these criticisms, talking about Seneca's "preconceived dislike" for Maecenas, or about the envy by Nero's minister of Augustus' minister, or about the rivalry of a Stoic against an Epicurean. ${ }^{19}$ Over the past fifteen years, the scene has been dominated by S. N. Byrne, who rejects the hypothesis of Seneca's personal aversion to Maecenas; ${ }^{20}$ starting from undeniable premises (the similarities between the character of Maecenas and Petronius and the parodic allusions to Seneca contained in the Satyricon), Byrne has developed the following theory: by criticizing Maecenas, Seneca actually attacks Petronius, who responds in his turn by assigning "maecenatian" features to his character Trimalchio (precisely defined as Maecenatianus in Petr. 71. 12). ${ }^{21}$ This theory of "mutual parody" (as Byrne calls it) ${ }^{22}$ may seem cumbersome, but it is well articulated and significantly enhances the allusive intertextuality ${ }^{23}$ between Maecenas (and his writings), Seneca, Petronius, and even Tacitus (who, in Byrne's opinion, through Maecenas, subtly criticizes the secret activities of Augustan principate). ${ }^{24}$

${ }^{18}$ Seneca, Epistulae morales. Trans. by R. M. GUMMERE. London-Cambridge Mass. 1962.

${ }^{19}$ Maecenas' Epicureanism is a cornerstone of André's biography (see ANDRÉ [n. 2] 15-61) and seems to have generally influenced French scholarship (see LE DOZE: Quomodo [n. 6] 296 "l'epicureisme, question central pour expliquer la posture politique de Mécène"); in my opinion, the importance of philosophy in Maecenas' life has not to be so much emphasized (see MAZZOLI, G.: L'epicureismo di Mecenate e il Prometheus. Athenaeum 40 [1968] 300-326, here 307 n. 17) and Seneca's 'philosophical' criticism against Maecenas may be read with a stylistic perspective (SETAIOLI, A.: Facundus Seneca. Aspetti della lingua e dell'ideologia senecana. Bologna 2000, 258-273).

${ }^{20}$ BYrne, S. N.: Petronius and Maecenas: Seneca's calculated criticism. In BYRNE, S. N. - CUEVA, E. - Alvares, J. (eds.): Authors, Authority, and Interpreters in the Ancient Novel: Essays in Honour of Gareth L. Schmeling. Groningen 2006, 83-111, here 95.

${ }^{21}$ An accurate survey of the similarities between the two characters now in BYRNE, S. N.: Maecenas and Petronius' Trimalchio Maecenatianus. AncNarr 6 (2007) 31-50, here 39-46.

22 BYRnE: Petronius (n. 20) 102

${ }^{23}$ Concerning this field of research, Byrne's studies could be considered an excellent contribution to Sullivan's "Neronian literary feud"; appreciations for her method - even if not for her results - come also from LABATE, M.: Mecenate senza poeti, poeti senza Mecenate: la distruzione di un mito augusteo. In BASTIANINI, G. - LAPINI, W. - TUlli, M. (a c. di): Harmonia. Scritti di filologia classica in Angelo Casanova. Firenze 2012, 405-424, here 416 "l'idea che [...] Shannon Byrne propone con impegno, anzi quasi con accanimento".

${ }^{24}$ Byrne, S. N.: Pointed allusions: Maecenas and Sallustius in the Annals of Tacitus. RhM 145 (1999) 339-345, here 341-343. 
It can seem excessive, however, that the two Neronian authors have deliberately bent Maecenas' character to their purposes; more simply, a few years ago, M. Labate and R. Degl'Innocenti Pierini ${ }^{25}$ recognized in Seneca's (and Petronius') representations of Maecenas the proof that Maecenas was well known for his worst features in the Julio-Claudian Age. Seneca and Petronius have merely drawn, and loaded with a bit of Neronian emphasis, ${ }^{26}$ information from a well-rooted tradition, a real scandalmongering dossier probably composed against Maecenas in Triumviral Age; this dossier survived the Age of Augustus and consequently Maecenas represented a false note in the reception of this Age realistically defined "eccellente, ma non troppo". 27

About Maecenas and the poets I shall say less than one might expect. Avallone has done a comprehensive review of major and minor poets of the "circle of Maecenas" and André has tried to illustrate its cultural implication in Augustan policy. ${ }^{28}$ However, if we look for details about the activity of the circle and its master in the Augustan authors, they give us almost the same information that Horace gives to the Bore in Hor. S. 1. 9. 43-52: they say as little as possible and describe an absolutely idealized picture of restricted friendship (recent studies, more truthfully, remind us that the amicitia between poets and patron maintained traits of patron-client relationships) ${ }^{29}$ so the activity of Maecenas as a patron of letters appears elusive as his activity as a chamberlain.

In regard to the "antonomastic" myth of Maecenas as patron of letters, a very complete analysis is provided by F. Bellandi, which states that the Augustan poets had composed "una sorta di patrimonio di immagini pronto al re-impiego simbolico" 30 on Maecenas' patronage. However, between the first and second centuries a few verses of Laus Pisonis (230-248) will develop these assumptions, offering an organic - and idealized - image of Maecenas as patron of poets. Excepting the anonymous of Laus Pisonis, Labate has recently suggested an interesting way of reading the other sources on Maecenas of this period: "Mecenate senza poeti, poeti senza Mecenate: la distruzione di un mito augusteo.", 31

${ }^{25}$ LABATE (n. 23); Degl'InNOCENTI PIERINI, R.: Seneca, Mecenate e il 'ritratto in movimento' (a proposito dell'epistola 114). In GASTI, F. (a c. di): Seneca e la letteratura greca e latina. Per $i$ settant'anni di Giancarlo Mazzoli. Atti della IX Giornata Ghisleriana di Filologia Classica. Pavia 2013, 45-65.

${ }^{26}$ See similarly BYRNE: Petronius (n. 20) 105 "Seneca had only to exaggerate characteristics about the real Maecenas that most ancient authors passed over without comment".

${ }^{27}$ See BERNO, F. R.: Eccellente ma non troppo: l'exemplum di Augusto in Seneca. In LABATE, M. RosAti, G. (a c. di): La costruzione del mito augusteo. Heidelberg 2013, 181-196, here 187-188. Under the caricatural representation of Seneca's Maecenas could be hidden also a subtle accusation against Nero, see TAKÁCS, L.: Metamorphosis and disruption. Comments on Seneca 114th epistula moralis. AA Hung 45 (2005) 407-411.

${ }_{28}$ AVAllone (n. 2) 167-201; ANDRÉ (n. 2) 97-143.

${ }^{29}$ WHITE, P.: Friendship, patronage and Horatian socio-poetics. In HARRISON, S. (ed.): The Cambridge Companion to Horace. Cambridge 2007, 195-206, here 197-198; LE M. DUQUESNAY, I. M.: Horace and Maecenas: The Propaganda Value of Sermones I. In FREUDENBURG, K. (ed.): Horace: Satires and Epistles. Oxford 2009, 42-101, here 49-54.

${ }^{30}$ Belland, F.: L'immagine di Mecenate protettore delle lettere nella poesia fra I e II sec. d. C. $A \& R \quad 40$ (1995) 78-101, here 78.

${ }^{31}$ LABATE (n. 23). 
The former part of this interpretation (Maecenas without poets) corresponds to the Maecenas of the tradition used by Seneca, Petronius and the apologetic elegies themselves, which - and this is noteworthy - do not use Maecenas' fame as leader of Augustan poetry to defend him; it might be the proof that this fame was shaded by the infamy of his eccentric behaviour. ${ }^{32}$ Therefore, Maecenas in the first and second century represents the stereotype of an overly refined man (see also Iuv. 1. 66; 12. 39; Mart. Ep. 10. 73.4) much more than an antonomasia of a generous patron of literature.

The latter part of Labate's definition (Poets without Maecenas) hints, to speak approximately, at those poets of the Flavian and Antonine Age (Martial and Juvenal) who celebrate Maecenas as an unachievable myth in the contemporary crisis of patronage; consequently, since this crisis feeds their spirit of biting polemic, the recalling of Maecenas' patronage is also "brutalized" and materialized. The "Maecenas", in many cases (Mart. Ep. 1. 107; 8. 55; 12. 3; Iuv. 7. 94-97), is simply the patron who pays and the poet is the client who writes. If we cannot say that the Augustan myth is completely "destroyed" by the satirical poets, we have to admit that it could often be injured.

In the frame of the Age of Augustus, then, a space should be reserved for Maecenas as a writer. ${ }^{33}$ Maecenas' compositions form an anthology of short fragments, handed down for the most part by Seneca (a further proof of his deep knowledge of Maecenas) as examples of bad - or at least bizarre - poetry, concerning metric, rhetoric and vocabulary. "Apologists" biographers have made an attempt to re-evaluate stylistically these fragments and tried to get from them features of Maecenas' personality (following the psychological interpretation of Bardon, who connected Maecenas' baroque stylistic tendency with his restless soul) $;^{34}$ their considerations are now essential, but criticism has gone beyond.

Byrne (2007) has recently warned against the dangers of looking for autobiographical elements in literary texts; for my part, I say that Maecenas' fragments might be more often regarded as a field of interaction between poet and patron in the context of artistic production. It would be sufficient to resume - and possibly develop Lunderstedt's and Avallone's commentaries in order to rediscover parallel passages of some interest. A few examples:

1. the correspondence between the fr. 19 Lund. and Prop. 3. 8. 37: nexisti retia lecto [you have woven a trap about my bed]

2. the common affection of Horace and Maecenas for some issues, such as the profession of modesty (fr. 3 Lund.), the reflection on death and post-mortem (frr. 6

\footnotetext{
${ }^{32}$ See now LE DOZE: Elegiae (n. 12) 299.

${ }^{33}$ Scholarship has paid quite little attention to prose fragments (exceptions are MAKOWSKY J. F.: Iocosus Maecenas: Patron As Writer. SyllClass 3 [1991] 25-35 and, more recently, BERTI, E.: Su alcuni frammenti di Mecenate trasmessi da Seneca (epist. 114. 5). Prometheus 40 [2014] 224-240, that I could not read); poetical fragments are better known, thanks to the anthological editions of COURTNEY, E.: The Fragmentary Latin Poets. Oxford $2003^{2}, 276-281$ and Hollis, A. S. (ed.): Fragments of Roman Poetry c. $60 B C-A D 20$. Oxford 2007, 314-325.

${ }^{34}$ BARDON, H.: La littérature latine inconnue. Vol. II. Paris 1956, 19.
} 
and 16 Lund.); some gallant scenes (fr. 15 Lund. $^{35}$ ), some supposed mythological variants, statements of friendship:

Maecenas:
Fr. 3 Lund. (Isid. or. 19. 32. 6)
Nec smaragdos
beryllos mihi, Flacce, nec nitentes
nec percandida margarita quaero
nec quos Thynica lima perpolivit
Flaccus, my life, I ask for myself neither
sparkling emeralds nor radiant beryls, nor
pure white pearls, not finger-rings which a
Thynian file has polished to be uttermost,
not pebbles of jasper [trans. A. S. Hollis]

Fr. 6 Lund. (Sen. ep. 92. 35)

Nec tumulum curo. sepelit natura relictos

I want no tomb; for Nature doth provide for outcast bodies burial

[trans. R. M. Gummere]

Fr. 16 Lund. (Quint. inst. 9. 4. 28)

Ne exsequias quidem unus inter

miserrimos viderem meas

May I never, alone admist the most miserable of men, behold my own funeral rites. [trans. H. E. Butler ${ }^{36}$ ]

Fr. 15 Lund. (GLK 2. 536. 7)

Pexisti capillum naturae muneribus gratum

You have combed your hair, pleasant gift from nature

\section{Horace:}

Hor. carm. 1. 31. 3-7

non opimae

Sardiniae segetes feraces, non aestuosae grata Calabriae armenta, non aurum aut ebur Indicum, non rura, quae Liris quieta not for the rich harvest of fertile Sardinia, not for the pleasant herds of hot Calabria, not for Indian gold or ivory, not for the fields that the Liris' silent stream [trans. C. E. Bennet ${ }^{37}$ ]

Hor. carm. 2. 20. 21-24

absint inani funere neniae luctusque turpes et querimoniae; compesce clamorem ac sepulcri mitte supervacuos honores.

Let dirges be absent from what you falsely deem my death, and unseemly show of grief and lamentation! Restrain all clamour and forgo the idle tribute of a tomb!

[Id.]

Prop. 1. 2. 1

Quid iuvat ornato procedere,

vita, capillo

What boots it, light of my life, to go forth with locks adorned?

[trans. H. E. Butler]

Hor. carm. 1. 5. 4-5

cui flavam religas comam

simplex munditiis?

For whom dost thou tie up thy golden hair in simple elegance?

[trans. C. E. Bennett]

${ }^{35}$ An exhaustive discussion about the supposed oratorical origin of this fragment in BALBO (n. 3) 20; we can remember that Nero has composed a poem on Poppaea's hair naming it sucini, a pretiosum nomen (Plin. nat. 37. 50) worthy of Maecenas' lexical affectation.

${ }^{36}$ Quintilian, The Institutio oratoria. Trans. by H. E. BUTLER. London-Cambridge Mass. 1968.

${ }^{37}$ Horace, The Odes and Epodes. Trans. by C. E. BENNET. London-Cambridge Mass. 1964. 
3. the intrusion of vulgar forms in poetry (bene est: fr. 1 Lund. Ov. Pont. 3. 9. 6 $\sim$ Hor. Sat. 2. 6. 4);

4. Finally, and above all, the contrast between some involved expressions of Maecenas' style and the more classical outcomes of his poets: we can see that in texts a) and $\mathrm{a}^{1}$ ) the image of the woods reflected in the water of a river is quite the same, but Virgil doesn't share the almost absurd (or, at least, expressionistic) turn of phrase of his patron, who says that the river (literally) "bears leaves" like the woods. In $b^{1}$ ) Virgil personifies the lands, saying that they "withdraw"; in b) this personification is lexically more daring, because the horti are not simply the subject of an intransitive verb, but the object of an action done by some men who "push back" the gardens; this form is better comparable with some verses of Ovid $\left(\mathrm{b}^{2}\right)$, who was a poet undoubtedly more inclined to innovation than Virgil:

a) Fr. 11 Lund. (Sen. ep. 114. 5) Amne silvisque ripa comantibus A stream and a bank covered with longdressed woods [trans. R. M. Gummere]

b) Remittant hortos men leave gardens behind them

\section{a $^{1}$ ) Verg. $A .8 .96$}

Viridisque secant placido aequore silvas

they cleave the green woods on the calm surface [trans. R. Rushton Fairclough ${ }^{38}$ ]

\section{$\left.b^{1}\right)$ Verg. A. 3. 72}

[Id.] Terrae ... recedunt

Lands ... fade from view

[Id.]

\section{$\left.b^{2}\right)$ Ov. met. 2. 786; 6. 512}

Tellurem reppulit hasta

She pushed back the land with

her spear

[trans. F. J. Miller ${ }^{39}$ ]

Tellusque repulsa est

The land was left behind

Maecenas' prose and poetry, eccentric as his behaviour, are a (little) bridge thrown by the Augustan literature between Neoteric poets and Novelli, ${ }^{40}$ but above all, Maecenas' artistic osmosis with his poets demonstrates that Maecenas personally shared the responsibility and the oscillations of literary taste of the literature he promoted; 1967.

${ }^{38}$ Virgil, Eclogues. Georgics. Aeneid. Trans. by H. R. FAIRCLOUGH. London-Cambridge Mass.

${ }^{39}$ Ovid, Metamorphoses. Trans. by F. J. MiLLER. London-Cambridge Mass. 1921-1922.

${ }^{40}$ An exhaustive discussion in MATTIACCI, S.: L'attività poetica di Mecenate tra neoterismo e novellismo. Prometheus 21 (1995) 67-86. 
we know from Seneca the Elder (suas. $1.12 ; 2.20$ ) that Maecenas was a fine literary critic and his fragments confirm his interest in contemporary poetry and stylistic research. $^{41}$

I would like to propose a last hint of research, more original and, at least for me, absolutely in progress: Maecenas in the scholia. The field of scoliastica requires cautious critical premises, which I will perhaps develop in an independent paper but I have to omit now. The scholia collect heterogeneous material, whose source is often indefinable and that always goes beyond the classical age, as we shall see. However, they may be the testimonies of a marginal tradition, sometimes a bit naive, but often well-established or, sometimes, they can preserve unheard information. Petrarch's note in Verg. ecl. 1. 57, for example, recalls Maecenas as an example of marital agreement, shocking anyone who has read about his wife Terentia's cottidiana repudia, testified by Sen. prov. 3. 11, or her adulterous affairs remembered by Dio Cassius 54 . 19. 3-6.

Moving to more serious topics, we note that the oldest scholia (Servius on Virgil, Porphyrion and Ps.-Acro on Horace) often relate the nobility of Maecenas and his rejection of the senatorial dignity (e.g. Ps.-Acro ${ }^{42}$ in Hor. S. 1. 1. 1-2), two elements clearly testified to by historians (Vell. Pat. 2. 88. 2 angusti clavi †paene $\dagger$ contentus). This refusal of the senatorial dignity, so little worthy of a Roman noble, has been interpreted by biographers of our times as a sign of the modesty of Maecenas or as a tribute to Epicurean philosophy, notoriously an enemy of public offices; ${ }^{43}$ Prop. 3. 9. 29 (Parcis et in tenuis humilem te colligis umbras [yet you hold back and humbly withdraw to a modest background; trans. H. E. Butler]) seems to support such a reading. The acute and more experienced eye of L. Aigner Foresti, ${ }^{44}$ however, has interpreted it, on the contrary, as a sign of snobbery towards a power more formal than substantial and towards an institution (the Augustan Senate) recently filled with parvenues (including Maecenas' - plebeian - colleague, Agrippa; see on this subject the funny anecdote of Sen. Contr. 2. 4. 13). ${ }^{45}$

${ }^{41}$ See also Sid. Apoll. carm. 4. 5-7 at mihi Petrus erit Maecenas temporis huius ... si probat, emittit, si damnat carmina celat, cited by Etienne Wolff, "The Image of Augustus in the Work of Sidonius Apollinaris", in this same volume, pp. 469-475.

${ }^{42}$ For the identity of Ps.-Acro, see ElLIOTT, J.: Ennius and the Architecture of the Annales. Cambridge 2013,548 .

${ }^{43}$ AVAllone (n. 2) 21-22, 49; ANDRÉ (n. 2) 75-84, 93-96.

${ }^{44}$ AIGNER FORESTI, L.: Quod discinctus eras, animo quoque, carpitur unum. In SORDI, M. (a c. di): L'immagine dell'uomo politico: vita pubblica e morale nell'antichità. Milano 1991, 201-214, here 207 n. 61 .

${ }^{45}$ I make my considerations about Maecenas' equestrian state from a literary point of view. A historical analysis dealing with political and juridical problems could suggest different observations; I thank Elena Caliri who has reminded me of the lex Valeria Cornelia, that defined the constitutional roles of senators and knights: see for details BRUNT, P. A.: The Lex Valeria Cornelia. JRS 51 (1961) 71-83; about Augustan institutions in the restauratio Rei publicae after the civil war, see LE DOZE: Quomodo (n. 6) 113; CRESCI, G.: Maecenas, equitum decus. RSA 25 (1995) 169-176, here 175, speaks about a "strategia di riequilibrio tra ordines"; DÉMOUGIN, S.: L'ordre équestre sous le Julio-Claudiens. Rome 1988, 156161 catalogues all the lectiones senatus and the census of Augustan age, but, at the end, remembers that Maecenas made a free choice in remaining in his state (752, n. 292 "Ce choix est toujours fortement marqué dans les sources"). 
Strongly opposed to recognizing the modesty of Maecenas is also the tradition of the scholia to Juvenal; describing, in the first satire, a successful forger so enriched with his profession as to travel on a luxury sedan-chair, Juvenal defines him as (1. 66) multum referens de Maecenate supino. Modern commentaries, including the excellent Stramaglia, believe Maecenas is here recalled as a prototype of a debauched man. $^{46}$ The scholia, however, explain supinus as superbus, proud of his Etruscan nobility.

Schol. vetera in Iuvenalem [IV-V cent.; ed. P. Wessner] De Maecenate supino: superbo vel mortuo: mortuo vel certe superbo et erecto de nobilitatis fastu

proud or dead: dead or more probably proud and bold because his nobility

Schol. in Iuv. recentiora [IX-X cent.; ed. S. Grazzini]

Referens: Maecenas ... secundum generis claritatem, mores habebat sublimes et ... erat ille solitus se magnificare sapientia, nobilitate et largitate

Maecenas ... in accordance with his family-background, was splendid in his behaviour, and ... he used to magnify his knowledge, nobility and liberality

Schol. in Iuv. recentiora [< XII cent.; ed. B. Löfstedt] B (Oxford, Bodleian Library Auct. F 6,9)

De Mecenate s(upino): Mecenas fuit signator Augusti Caesaris et cancellarius, cuius dignitas ad ipsum pervenerat, unde iste multum iactabat et ob superbiam supinus incedebat.

Maecenas was Augustus' secretary and chamberlain and shared the same authority of his master; he was very proud of it and, because this haughtiness, he walked with haughty attitude

$\mathrm{P}$ (Paris, Bibliothèque Nationale, lat. 2904)

De supi(no) (id est superbo) Mece(nate). Mecenas familiaris fuit Augusti Cesaris probus multum, sed superbus.

Maecenas was the friend of Caesar Augustus, an excellent man, although arrogant

W (Baltimore, Walters Art Gallery 20)

De Me(cenate) supino: id est superbo. ... enim Mecenas pro familiaritate Augusti ex superbia supinus incedebat

${ }^{46}$ StramagliA, A.: Giovenale, Satire 1,7,12,16. Storia di un poeta. Bologna 2008, 57. 
it means bold ... Maecenas indeed, proud of his friendship with Augustus, walked with haughty attitude

Bern (Bern, Burger-Bibliothek A 61)

Mecenas: fuit signator Augusti, cuius dignitas ad istum pervenerat, unde iste multum iactabat.

he was Augustus' secretary and acquired his power, a thing which he boasted much of

We can notice how the topic of superbia Maecenatis/supinus Maecenas, already mentioned in scholia of late antiquity (IV-V cent.), has grown stronger during the Middle Ages (IX-X cent.) and has been finally related to his friendship with Augustus ${ }^{47}$ by the scholia of late Middle Ages (XII cent.). The tradition preserved in these scholia (from V to XII cent.) describes a Maecenas less idealized than the modest man reluctant to be involved in public affairs as the biographers of our age want to show us; Maecenas' character as it appears in medieval scholia seems indeed more comparable with the man - maybe more realistically - described by historians and prose writers (we may include Seneca) of the first imperial age (from Velleius to Tacitus): a man who was well conscious of his uncommon nobility but, above all, proud of that private authority (see the signum, the dignitas) he shared with his powerful amicus. Because of this privileged condition, he could ignore the conventions of Roman society, contemning the traditional political career and ostentatiously (also haughtily) displaying his eccentric behaviour. We can quickly point out some similar expressions: Schol. Iuv. rec. B and W [XII sec.]: incedebat Sen. ep. 114. 6: incesserit; Schol. Iuv. rec. B and Bern [id.]: iactabat Tac. ann. 3. 30: ostentabat; Schol. Iuv. rec. [IX sec.]: mores ... sublimes $\sim$ Tac. ann. 3. 30: per cultum et munditias ... luxu.

I hope the reader will excuse this anthologic series of ancient sources, Medieval scholia, and studies of contemporary critics which, all together, probably would have satisfied Marquise de Rambouillet's curiosity less than Balzac's discourse alone. Scholars of the twentieth (and, now, of the twenty-first) century have said about Maecenas much more than the ancients and it may be unnecessary to say even more. I must admit however that both his character and the liveliness of the critical studies relating to him arouse curiosity and the desire to draw more and more attention - with the constant risk of congestion - to the image of this elusive cornerstone of the Age of Augustus.

Stefano Costa

Università degli Studi di Milano

${ }^{47}$ According to this scholiastic interpretation an ulterior parallelism could be instituted between the gemma uda (Iuv. 1. 68) of signator falsi and the signum bestowed by Augustus to Maecenas (Sen. ep. 114.6) as the sign of supreme power; for its political value see LE DOZE: Aux origines (n. 8) 109-110. 